\title{
IMPLEMENTASI PROGRAM MANAJEMEN BKI DALAM MENGATASI MASALAH KESISWAAN DI MTSN PANAMPUANG
}

\author{
Muhammad Hafizh \\ Wiraswasta di Kabupaten Tanah Datar, \\ Alamat: J orong koto Tuo Nagari Panyalaian Kab Tanah Datar, HP. 082390791004, \\ e-mail:muhammdhafizh062@gmail.com

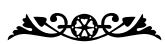

\begin{abstract}
The purpose ofthis study to determinethe implementation of management program of the critical BKI, according tothe rules ofthe existing curriculum conceptsin MTsN panampuang with the fact that there are in the fiel das well asstudent achievementas a referencefor teachers in evaluating learning and improve student achievement MTsNpanampuang. Found some cases in which students MTsN Panampuang inhibit the learning process. The results of the interview panel of teachers and community leaders found some problems criterion mild, moderate, and severe that in habit learning objectives, such as sexual immorality, poor discipline and extracurricular school programs are rarely attended by the students. Moral character and the lower its value, and some cases of discipline such as skipping, no school extracurricular programs, as well as the difficulty of assembly of teachers in classroom management problems occur due to the number of student. The conclution is management in the Islamic Counseling MTsN Panampuang been effective because management has reached an ideal standard concept in schooll, but not efficient because it has not reached the goal of shaping the character and resolve student issues. Organizing theim plementation of theI CC in MTsN Panampuang management does not give effect to the number of student problems.
\end{abstract}

Key Words: Implementasi, manajemen BKI, masalah siswa

\section{PENDAHULUAN}

MTsN Panampuang yang berada di kanagarian Panampuang kecamatan IV Angkek Kabupaten Agam ,Menurut catatan Inyiak Aguang, sekolah ini didirikan oleh Inyiak Thaib Labai Mudo pada tahun 1932 bertempat di rawang surau lawik. awalnya sekolah ini merupakan halaqah yang mengajarkan ilmu Tauhid, Fiqih, Nahu. Sharaf, bagi masyarakat Surau Lawik akan tetapi mengalami perkembangan halaqah tersebut di ubah menjadi sekolah untuk MTsN panampuang yang mempunyai visi mendalami ilmu agama bagi generasi Panampuang pada awal pendirian MTsN tersebut.

Bedasarkan observasi awal dilapangan interaksi proses belajar mengajar di MTsN Panampuang mengalami kesulitan belajar yang disebabkan oleh faktor kenakalan remaja seperti berdasarkan beberapa kasus siswa siswi yang bermesraan dalam jam sekolah atau berpacaran dan sikap malas dalam proses belajar mengajar seperti tidak efektif menghafal alquran dan memenuhi kegiatan 
ekstrakurikuler yang diprogramkan sekolah akan tetapi pengaruh pengelolaan program bimbingan konseling di sekolah seolah dalam melihat kondisi siswa disekolah belum menunjukan performa idealnya. Adapun yang dimaksud dengan kesulitan belajar adalah kendala-kendala yang dihadapi pada waktu proses belajar mengajar yang disebabkan oleh beberapa faktor sehingga tujuan pembelajaran tidak tercapai secara maksimal. Misalnya, kemampuan belajar yang rendah, motivasi belajar yang rendah, perilaku menyimpang dalam belajar, dan prestasi belajar yang rendah. Jadi kesulitan belajar adalah suatu keadaan dimana anak didik tidak dapat belajar dengan semestinya.

Ditemukan beberapa kasus kenakalan remaja yang tercatat dalam buku hitam kepegawaian sekolah seperti merokok, minum minuman keras, berbuat aniaya kepada guru dengan contoh prilaku menyimpang terhadap guru, dalam 10 tahun terakhir ini paling kurang dua kali dalam satu tahun terjadi penangkapan siswa siswi yang sedang bermesraan, ini menampakan terkikisnya moral serta kurangnya disiplin dalam diri siswa seperti tidak melakukan kegiatan pramuka , kegiatan muhadarah serta kegiatan kesenian , teralambatnya membayar uang spp dan sering penuhnya buku hitam dengan keterlabatan siswa ke sekolah dan seringnya siswa bolos belajar. Dan apabila dibandingkan dengan sekolah lain hal ini sangat memprihatinkan dan apabila dibiarkan berlarut larut akan mengikis moral siswa dan hilangnya nilai nilai keislaman dalam interaksi di keluarga, disekolah dan diluar sekolah.
Menjadi fokus penelitian dalam pembahasan ini adalah bagaimana implementasi perencanaan,pengorganisasi an,pelaksanaan serta pengawasan program bimbingan konseling islam dalam mengatasi masalah kesiswaan di MTsN panampuang. Menurut Haiman sebagaimana dikutip oleh M. Manulang, manajemen adalah fungsi untuk mencapai sesuatu melalui kegiatan orang lain dan mengawasi usaha-usaha individu untuk mencapai tujuan bersama.

Menurut James A. F. Stoner sebagaimana dikutip oleh A. M. Kadarman dkk menyebutkan: Manajemen adalah proses perencanaan, pengorganisasian, memimpin dan mengendalikan berbagai upaya dari anggota organisasi dan proses penggunaan sumber daya orang demi tercapainya tujuan organisasi yang telah ditetapkan.

MenurutMalayu, S. P Hasibuan: Manajemen adalah ilmu dan seni mengatur pemanfaatan sumber daya manusia dan sumber daya lainnya secara efektif dan efesien untuk mencapai suatu tujuan tertentu. Menurut H. Koontz and O. Donnel, sebagai berikut "Managemen involves getting thing done throught and with people", artinya: Manajemen berhubungan dengan pencapaian sesuatu tujuan yang dilakukan melalui dan dengan orang lain.MenurutWinardi yang dikutip oleh Ishak Saleh, manajemen merupakan sebuah proses yang khas yang terdiri dari tindakantindakan perencanaan, pengorganisasian, penggerakan dan pengawasan yang dilakukan untuk mencapai sasaran-sasaran yang ditetapkan melalui pemanfaatan sumber daya manusia serta sumber-sumber lainnya. 
Dari berbagai defenisi tentang manajemen yang dikemukakan oleh para pakar di atas dapat penulis ambil suatu kesimpulan, bahwa manajemen adalah ilmu, seni, proses, aktivitas dan usaha yang dilakukan oleh seorang manajer untuk menggerakkan orang lain dengan melaksanakan seluruh fungsi seperti perencanaan, pengorganisasian, penggerakan dan pengawasan dengan memanfaatkan sumber daya manusia dan sumber daya alam untuk tercapainya tujuan secara bersama yang telah ditetapkan.

Prinsip-prinsip organisasi BKI MTsN Panampuang, secara umum dapat dijelaskan sebagai berikut :

1. Organisasi harus mempunyai tujuan pemebntukan karakter siswa. Organisasi dibentuk atas dasar adanya tujuan yang ingin dicapai, sehingga tidak mungkin suatu organisasi tanpa adanya tujuan.

2. Prinsip skala hierarki.Dalam satuan organisasi BKI , garis kewenangan yang jelas dari pimpinan kabid $\mathrm{BKi}$, pembantu pimpinan sampai pelaksana, sehingga dapat mempertegas dalam pendelegasian wewenang dan pertanggung jawaban, dan akan menunjang efektivitas jalannya organisasi BKI secara keseluruhan di MTsN Panampuang. Personilnya semua majlis Guru MTsN Panampuang bekerja sama dalam mengkondusifkan suasana belajar dan penanaman karaker siswa MTsN Panampuang.

3. Prinsip kesatuan perintah melalui program BKI MTsN panampuang. Dalam hal ini, Staf BKI dan guru bidang study hanya menerima perintah atau bertanggung jawab kepada kepala sekolah setelah melakukan prosedur yang berlaku.

4. Prinsip pendelegasian wewenang. Kepala Bidang BKI ata kepala sekolah MTsN panampuang mempunyai kemampuan terbatas dalam menjalankan pekerjaannya, sehingga perlu dilakukan pendelegasian wewenang kepada bawahannya. Guru yang diberi wewenang harus dapat menjamin tercapainya hasil yang diharapkan dalam mengatasi masalah kesiswaan.

5. Prinsip pertanggung jawaban. Dalam menjalankan tugasnya guru BKI harus bertanggung jawab sepenuhnya kepada kepala sekolah.

6. Prinsip pembagian pekerjaan. Suatu organisasi, untuk mencapai tujuannya, melakukan berbagai aktivitas atau kegiatan. Agar kegiatan dapat berjalan optimal, dilakukan pembagian tugas/ pekerjaan yang didasarkan pada kemampuan dan keahlian dari tiaptiap pengurus job description yang efektif dalam pembentukan karakter dan mengatasi masalah kesiswaan.

7. Prinsip rentang pengendalian. Artinya bahwa jumlah bawahan atau staf yang harus dikendalikan oleh kepala bidang bki perlu dibatasi secara rasional. Rentang kendali ini sesuai dengan bentuk dan tipe organisasi BKI yang mengagani masalah fisik dan psikisnya siswa . Semakin besar suatu organisasi dengan jumlah pegawai yang cukup banyak, semakin komplek rentang pengendaliannya.

8. Prinsip fungsional. Secara fungsional, tugas dan wewenang, kegiatan, hubungan 
kerja, serta tanggung jawab guru guru di $\mathrm{MTsN}$ panampuang harus jelas.

9. Prinsip pemisahan. Tanggung jawab tugas pekerjaan seseorang tidak dapat dibebankan kepada orang lain.

10. Prinsip keseimbangan. Keseimbangan di sini adalah keseimbangan antara struktur organisasi yang efektif dan tujuan organisasi.

11. Prinsip fleksibilitas. Organisasi BKI harus senantiasa melakukan pertumbuhan dan perkembangan sesuai dengan dinamika organisasi sendiri dan karena adanya pengaruh di luar organisasi, sehingga organisasi mampu menjalankan fungsi dalam mencapai tujuannya.

12. Prinsip kepemimpinan. Dalam organisasi, apa pun bentuknya diperlukan pemimpin atau dengan kata lain, organisasi mampu menjalankan aktivitasnya karena adanya proses kepemimpinan yang digerakkan oleh pemimpin organisasi tersebut.

\section{PEMBAHASAN}

Penenelitian ini data yang hendak dikumpulkan adalah tentang Manajemen Bimbingan Konseling Islam untuk mengatasi maslah kesiswaan di MTsN panampuang Sumatera Barat. Dari ungkapan konsep inidikehendaki suatu informasi yang bersifat deskriptif, karena itulah penelitian ini menggunakan pendekatan kualitatif.

Alasan penulis memakai jenis penelitian kualitatif adalah karena penelitian yang akan penulis lakukan sesuai dengan ciri-ciri dari penelitian kualitatif seperti yang diungkapkan
Bogdan dan Biklen, yaitu:Qualitative research has the natural setting of the direct sourcecof data and the research the key instrument, qualitative research is descriptive, qualitative research are concerned with process rather then simply with outcomes or product, qualitative research tend the analyze their data inductively, "meaning" is of essential concern to the qualitative approach.

Ciri-ciri penelitian kualitatif adalah: memiliki latar alamiah sebagai sumber data langsung dan peneliti adalah istrumen kunci, bersifat deskriptif, peneliti-peneliti kualitatif lebih memperhatikan proses dari pada hasil, peneliti cenderung menganalisis data sqecara induktif dan makna menjadi perhatian dalam pendekatan kualitatif.

Dalam penelitian tentang Implementasi manajemen bimbingan konseling Islam dalam meqngatasi masalah kesiswaan di MTsN Panampuang Kabupaten Agam Sumatera Barat, penulis ingin mendapatkan gambaran apa adanya tentang pelaksanaan manajemen bimbingan konseling Islam dalam mengatasi masalah kesiswaan. Dalam penelitian ini, sebagaimana pendapat ahli di atas, penulis lebih mengutamakan proses dari pada hasil dan menggunakan sumber data yang bersifat alamiah.

\section{TEMUAN PENELITIAN}

Dari pembahasan penelitian dapat dikemukakan beberapa temuansebagai berikut:

1. Perencanaan manejemen bimbingan konseling Islam di Madrasah Tsanawiyah Negeri Panampuang didasari kepada banyaknya kasus kasus yang terjadi dalam 
lingkungan sekolah dan masyarakat. Pada awalnya, di MTsN ini program yang dilaksanakan dalam mengatasi masalah kesiswaan dan penanaman nilai nilai akhlak yaitu dengan bantuan Guru BP. Guru BP yaitu Bimbingan Penyuluhan.

Guru berperan sebagai sahabat dalam menunjang kelancaran tercapainya tujuan siswa dalam belajar. Guru bisa menjadi orangtua yang mengarahkan dan membimbing ketika siswa melakukan kesalahan dan bisa menjadi teman sejati tempat mendapatkan informasi, curhat,konsultasi dan solusi saat murid mengalami permasalahan. Siswa yang bermain ke ruang BP bukan berarti bermasalah. agar peran BP dapat maksimal sesuai dengan yang diinginkan maka kerjasama keduabelah pihak tentulah sangat menentukan dalam mengatasi masalah kesiswaan akan tetapi adanya guru Bp kurang efektif setelah banyaknya laporan masyarakat tentang kenakalankenakalan siswa yang terjadi di masyarakat seperti kasus penangkapan siswa siswi yag bermesraan di luar sekolah dan pemeriksaan handphone yang berisikan media online yang berbau porno serta kenakalan dalam proses belajar mengajar disertakan tidak disiplinnya siswa dalam belajar dan mengikuti kegiatan ekstrakurikuler.

Atas dasar pemikiran itulah guru BP MTsN Panampuang berencana membuat program konseling terpadu dan memperbincangkannnya dengan Waka kurikulum dan mengomunikasiakan ke kepala sekolah dan mencanangkan program bimbingan konseling. Pada awalnya dengan proses melapornya guru BP kepada Waka kurikulum sekolah tentang sulitnya guru BP dalam menangani banyaknya masalah siswa yang terjadi beberapa tahun ini dari yang terjadi didalam madrasah dan diluar madrasah yang menyangkut siswa MTsN panampuang serta memberi pertimbangan bahwa perlu diadakannya sebuah program yang menyangkut masalah siswa dan pembentukan akhlak siswa di dalam dan luar lingkungan sekolah guna pengkaderan ulama di Nagari Panampuang khususnya

2. Pengorganisasian program BKI MTsN Panampuang merupakan kegiatan pengaturan kegiatan Bimbingan dan Konseling Islam yang meliputi cara kerja dalam mengahadapi masalah siswa dan prosedur kerja dalam menjalankan roda organisasi BKI.

Hal yang dilakukan dalam pengorganisasian program Bimbingan dan Konseling Islam adalah Penghimpunan semua komponen di sekolah yaitu kepala sekolah, guru mata pelajaran, wali kelas,guru pembimbing/ konselor,dan tata usaha dalam satu wadah organisasi di MTsN.Serta penetapan mekanisme kerja tunggal dalam pelaksanaan yang dilakukan oleh semua guru pembimbing/konselor yang ada di MTsN Panampuang. Perincian dengan jelas tugas dan tanggung jawab setiap guru pembimbing dan konselor yang berada di MTsN panampuang. Dasar bagi organisasi bimbingan dan konseling 
BKI adalah adanya kesepakatan bersama antar pengurus BKI dalam organisasi BKI. Atas dasar kesepakatan itu, pengelolaan dan penyelenggaraan bimbingan dan konseling dapat melibatkan semua pihak di MTsN panampuang termasuk masyarakat sekitar MTsN panampuang.

3. Pelaksanaan Program BKI di MTsN Panampuang di prioritaskan dalam meningkatkan control social masyarakat terhadap siswa MTsN panampuang akan tetapi dalam tinjauan konsep kurikulum BKI banyak terdapat poin point yang harus dilaksanakan dalam program akan tetapi fakum dilaksanakan seperti konsep ideal BKI di MTsN panampuang.idealnya layanan bimbingan dan konseling dilakukan melalui kontak langsung dengan siswa, dan secara langsung berkenaan dengan permasalahan ataupun kebutuhan tertentu yang dirasakan siswa. Kegiatan layanan itu difokuskan kepada salah satu atau beberapa kompetensi yang hendaknya dicapai dikuasai siswa jika pelaksanaannya dilakukan dengan terstruktur menurut konsep yang ada dalam kurikulum BKI sekolah.

4. pengawasan yang dilakukan kepala sekolah terhadap program BKI di MTsN Panampuang tidak efektif dikarenakan persepsi kepala sekolah terhadap Staf BKI sangat sibuk dalam mengurus jabatan lain disekolah sehingga pengawasan hanya bersifat formalitas dan tidak berpengaruh dalam mencegah masalah kesiswaan. Idealnya Kepala sekolah selaku penanggung jawab seluruh penyelenggaraan pendidikan di sekolah memegang peranan strategis dalam mengembangkan layanan bimbingan dan konseling di sekolah.

Dari uraian di atas dapat dimaknai bahwa kepengawasan merupakan kegiatan atau tindakan pengawasan dari kepala sekolah yang diberi tugas, tanggung jawab dan wewenang melakukan pembinaan dan penilaian terhadap guru.

Indikator peningkatan mutu pendidikan di MTsN Panampuang dilihat pada setiap komponen pendidikan antara lain: mutu lulusan, kualitas guru, kepala sekolah, staf sekolah (Tenaga Administrasi, Laboran dan Teknisi, Tenaga Perpustakaan), proses pembelajaran, sarana dan prasarana, pengelolaan sekolah, implementasi kurikulum, sistem penilaian dan komponen-lainnya.

Dalam pengawasan manajemen bimbingan program bimbingan konseling yang dilaksanakan di MTsN panampuang merupakan tanggung jawab kepala sekolah yang mempunyai hubungan yang sangat erat dengan fungsi-fungsi manajemen yang lainnya, terutama dengan fungsi perencanaan BKI itu sendiri. Ini berarti bahwa pengawasan tidak mungkin akan terlaksana tanpa adanya kegiatan perencanaan BKI , dan rencana tidak akan tercapai dengan optimal jika tidak disertai dengan pelaksanaan fungsi pengawasan BKI, dengan demikian perencanaan dan pengawasan dipandang sebagai mata rantai yang selalu berhubungan dan saling mempengaruhi.

Sondang P. Siagian memberikan pengertian pengawasan, yaitu proses pengamatan dari 
seluruh pelaksanaan kegiatan sebuah lembaga atau organisasi, agar semua kegiatan yang sedang dilakukan dapat berjalan sesuai dengan rencana yang telah ditetapkan. Oleh sebab itu pengawasan kepala sekolah terhadap program BKI dimaksudkan agar tujuan program BKI yang akan dicapai sesuai dengan perencanaan yang telah ditentukan atau tidak menyimpang dari perencanaan semula, Dalam pengawasan kepala sekolah memberikan kegiatan pemberian bimbingan, petunjuk atau instruksi dan bukan mencari kesalahan pada Kabid BKI melaksanakan program, tetapi berusaha untuk mencari kebenaran terhadap kinerja guru BK.

Dalam pelaksanaan pengawasan program BKI kepala sekolah mengevaluasi pegawasannya sendiri dengan pernilain yang objektif dengan criteria sebagai berikut:

1. Tertuju pada strategi sebagai kunci sasaran yang menentukan keberhasilan program BKI.

2. Kontrol menggunakan umpan balik dari pelaksana program BKI sebagai bahan revisi dalam mencapai tujuan program BKI pembentukan karakter siswa.

3. fleksibel dan responsive terhadap perubahan-perubahan kondisi dan lingkungan sekolah yang bernaung dalam lingkungan masyarakat panampuang yang heterogen.

4. Cocok dengan organisasi BKI

5. Merupakan kontrol diri sendiri.

6. Bersifat langsung yaitu pelaksanaan control dilaksanakn dilsekolah dan lingkungan luar sekolah dalam kanagarian panampuang.
7. Memperhatikan dan pengawasan terhadap guru BKI

8. Kepala sekolah MTsN Panampuang dalam pengawasannya rutin melihat kondisi sekolah dan melakukan koordinasi koordinasi dengan guru bimbingan konseling tentang peninjauan kondisi belajar dan penghambat motivasi siswa dalam belajar dengan bersifat observasi ,walaupun di MTsN Panampuang secara jelas dikatakan program BKI ini tidak utuh dijalankan dikarenakan padatnya jadwal kelas dan beratnya kompetensi kurikulum yang akan dicapai siswa maka kegiatan BKI hanya dilakukan dalam menghadapi masalah masalah yang sangat krusial maka pelayanan difokuskan terhadap siswa yang bermasalah, Sedangkan dalam segi sarana dan prasarana BKI di MTsN Panampuang serta kelengkapan bahan ajar serta buku buku siswa tentang bimbingan konseling sangat memadai dan itu tidak dipakai dikarenakan padatnya ketuntasan belajar yang ingin dicapai.

Sebagai kegiatan awal yang harus dilakukan oleh pimpinan dalam pelaksanaan manajemen adalah membuat perencanaan. Sebab setiap kegiatan akan dapat berjalan efektif dan efesien apabila telah direncanakan terlebih dahulu dengan matang. Hal ini sesuai dengan pengertian perencanaan itu sendiri, yaitu: keseluruhan proses pemikiran dan penentuan secara matang dari hal-hal yang akan dikerjakan dimasa yang akan datang dalam rangka pencapaian tujuan yang telah ditetapkan.

Adapun pengertian planning adalah perencanaan tentang apa yang akan dicapai, 
kemudian dijadikan pedoman terhadap apa yang akan diinginkan. Planning merupakan persiapan-persiapan pelaksanaan suatu tujuan yang biasanya mencakup berbagai kegiatan seperti merumuskan langkah-langkah kegiatan, menentukan kebutuhan yang diikuti oleh penentuan strategi, pencapaian tujuan dan kemudian penentuan program guna melaksanakan strategi tersebut.

Dari uraian di atas dapat dipahami bahwa perencanaan merupakan proses pemikiran dan pengambilan keputusan secara matang dan sistematis tentang tindakan-tindakan yang akan dilakukan pada masa yang akan datang dalam rangka pencapaian tujuan organisasi.

Kegiatan manajemen tidak hanya sampai kepada tahapan penyusunan rencana. Kegiatan selanjutnya adalah melaksanakan perencanaan itu secara operasional. Salah satu kegiatan manajemen dalam pelaksanaan suatu rencana disebut pengorganisasian. Pengorganisasian kata dasarnya adalah organisasi yang berasal dari bahasa Yunani yaitu "Orgonon", sedangkan istilah lainnya adalah "orgonum" yang berarti alat, bagian, anggota dan benda.

Pengorganisasian merupakan aktivitas membentuk hubungan-hubungan kerja antar orang-orang, sehingga terwujud suatu kesatuan usaha dalam mencapai tujuan yang telah ditetapkan. Dalam pengorganisasian terdapa adanya pembagian-pembagian tugas, wewenang dan tanggung jawab secara terperinci menurut bidang-bidang dan bagian-bagian sehingga tercipta hubungan kerja sama yang harmonis dan lancar dalam mencapai tujuan yang telah ditetapkan pada saat merumuskan perencanaan.
Istilah pengorganisasian mengandung dua pengertian umum. Pertama, organisasi diartikan sebagai usaha kelompok fungsional misalnya sebuah lembaga pendidikan, perkumpulan, badan usaha, pemerintahan dan sebuah perusahaan. Kedua, merujuk kepada proses pengorganisasian yaitu bagaimana pekerjaan diatur dan dialokasikan di antara para anggota, sehingga tujuan organisasi dapat tercapai secara efektif dan efesien.

Pengawasan merupakan fungsi manajemen yang mempunyai hubungan yang sangat erat dengan fungsi-fungsi manajemen yang lainnya, terutama dengan fungsi perencanaan. Ini berarti bahwa pengawasan tidak mungkin akan terlaksana tanpa adanya kegiatan perencanaan, dan rencana tidak akan tercapai dengan optimal jika tidak disertai dengan pelaksanaan fungsi pengawasan, dengan demikian perencanaan dan pengawasan dipandang sebagai mata rantai yang selalu berhubungan dan saling mempengaruhi.

Sondang P. Siagian memberikan pengertian pengawasan, yaitu proses pengamatan dari seluruh pelaksanaan kegiatan sebuah lembaga atau organisasi, agar semua kegiatan yang sedang dilakukan dapat berjalan sesuai dengan rencana yang telah ditetapkan.

Oleh sebab itu pengawasan dimaksudkan agar tujuan yang akan dicapai sesuai dengan perencanaan yang telah ditentukan atau tidak menyimpang dari perencanaan semula, maka pengawasan mengandung kegiatan pemberian bimbingan, petunjuk atau instruksi dan bukan mencari dan membebankan kesalahan pada orang yang melaksanakan program, tetapi 
berusaha untuk mencari kebenaran terhadap hasil pekerjaannya.

Jika dilihat dalam penerapan praktek dilapangan tentang Manajemen Bimbingan Konseling Islam di mTsN panampuang bisa digambarkan kekurangannya dari segi penerapan pengorganisasian yaitu dalam interaksinya dan guru bertugas bsetengah hati dalam menjalankan program dikarenakan sibuknya para majelis guru dalam menghadapi jadwal megajar yang padat sehingga dalam menjalankan programnya diwakilkan kepad staf kesiswaan dan guru BP atau guru yang pada waktunya kosong jam pelajaran dari segi perencanaan sudah matang dan apabila disorot dari segi pengawasan belum maksimal tercapai dikarenakan factor job description yang belum efektif kesalahn dari system disekolah dan kepala sekolah juga masih belum siap menerapkan program BKI secara maksimal dikarenakan menurut kepala sekolah tuntutan mata pelajaran kepada siswa sangat padat.

\section{PENUTUP}

Dari hasil penelitian dapat dikemukakan beberapa kesimpulan, sebagai berikut:Perencanaan program BKI di MTsN Panampuang sudah efektif dikarenakan sudah mencapai standar konsep manajemen yang ideal di sekolah, akan tetapi belum efesien karena belum mencapai tujuan untuk membentuk karakter dan mengatasi masalah kesiswaan. Pengorganisasian dalam Program BKI di MTsN panampuang tidak memberi pengaruh terhadap banyaknya masalah kesiswaan dikarenakan dalam proses koordinasi dalam pengorganisasian bidang bidang organisasi BKI terkendala dalam masalah sumber daya dan pembagian kerja yang tidak terstruktur dalam menghadapimasalah dilapangan ,dalam prakteknya melalan konsep kurikulum BKI yang ada serta Pelaksanaan Program BKI di MTsN Panampuang di prioritaskan dalam meningkatkan kontrol sosial masyarakat terhadap siswa MTsN panampuang akan tetapi dalam tinjauan konsep kurikulum BKI banyak terdapat poinpoin yang harus dilaksanakan dalam program akan tetapi fakum dilaksanakan seperti konsep ideal BKI di MTsN panampuang.

Idealnya layanan bimbingan dan konseling dilakukan melalui kontak langsung dengan siswa, dan secara langsung berkenaan dengan permasalahan ataupun kebutuhan tertentu yang dirasakan siswa. Kegiatan layanan itu difokuskan kepada salah satu atau beberapa kompetensi yang hendaknya dicapai dikuasai siswa jika pelaksanaannya dilakukan dengan terstruktur menurut konsep yang ada dalam kurikulum BKI sekolah.

Saran dalam hasil pembahasan penelitian ini adalah:

1. Dapat menerapkan program BKI yang ideal sehingga dapat membetuk karakter dan mengentaskan masalah kesiswaan untuk menunjang prestasi siswa.

2. Kepala sekolah dapat berkoordinasi dengan Dinas Departemen Agama dalam pembentukan rogram yang efektif dan bantuan dana guna memperlengkap sarana dan prasarana BKI.

3. Agar hasil penelitian inidapat menjadi bahan pertimbangan bagi pengurusatau kepala sekolah ke rah yang lebih baik 


\section{KEPUSTAKAAN ACUAN}

A. M. Kadarman, dkk, Pengantar Ilmu Manajemen, Jakarta: PT. GramediaPustaka Utama, 1997.

A. W. Widjaja dan M. Arsyik Hawab, Manajemen Bimbingan Konseling, Bandung:Graha Pustaka Mizan,2004.

Bogdan R and Biken Sk, qualitative research for Education, An Introduction to Theory and Method, Boston: Allyn and Bacon, 1982.

Elfi Muawanah,Rifa Hidayah, Bimbingan Konseling Islami, Jakarta: PT Bumi Aksara,2009.
Ishak Saleh, Manajemen Rumah Tangga, Bandung: Angkasa Bandung, 1993.

Jhon M. Echlos dan Hasan Shadili, Kamus Inggris Indonesia, Jakarta: Gramedia,1990.

M. Manulang, Dasar-Dasar Manajemen, Jakarta: t.p, 1996.

Malayu, S. P. Hasibuan, Manajemen Dasar, Pengantar dan Masalah, Jakarta:Bumi Aksara, 2001.

Syamsul, Bahri, Yoenoes,Manajemen Terpadu, Jakarta: Gudang Ilmu Press,2001. 